\title{
Reducing Cadmium Accumulation in Plants: Structure-Function Relations and Tissue-Specific Operation of Transporters in the Spotlight
}

\author{
Xin Huang ${ }^{1}$, Songpo Duan ${ }^{1}$, Qi Wu ${ }^{1}$, Min Yu ${ }^{1}$ and Sergey Shabala ${ }^{1,2, *}$ \\ 1 International Research Center for Environmental Membrane Biology, Foshan University, Foshan 528000, \\ China; Xin.Huang@utas.edu.au (X.H.); songpo.duan@hotmail.com (S.D.); qi.wu@fosu.edu.cn (Q.W.); \\ yumin@fosu.edu.cn (M.Y.) \\ 2 Tasmanian Institute of Agriculture, University of Tasmania, Hobart TAS 7001, Australia \\ * Correspondence: Seregy.Shabala@utas.edu.au
}

Received: 31 January 2020; Accepted: 6 February 2020; Published: 9 February 2020

\begin{abstract}
Cadmium (Cd) is present in many soils and, when entering the food chain, represents a major health threat to humans. Reducing $\mathrm{Cd}$ accumulation in plants is complicated by the fact that most known Cd transporters also operate in the transport of essential nutrients such as $\mathrm{Zn}, \mathrm{Fe}, \mathrm{Mn}$, or $\mathrm{Cu}$. This work summarizes the current knowledge of mechanisms mediating $\mathrm{Cd}$ uptake, radial transport, and translocation within the plant. It is concluded that real progress in the field may be only achieved if the transport of $\mathrm{Cd}$ and the above beneficial micronutrients is uncoupled, and we discuss the possible ways of achieving this goal. Accordingly, we suggest that the major focus of research in the field should be on the structure-function relations of various transporter isoforms and the functional assessment of their tissue-specific operation. Of specific importance are two tissues. The first one is a xylem parenchyma in plant roots; a major "controller" of Cd loading into the xylem and its transport to the shoot. The second one is a phloem tissue that operates in the last step of a metal transport. Another promising and currently underexplored avenue is to understand the role of non-selective cation channels in $\mathrm{Cd}$ uptake and reveal mechanisms of their regulation.
\end{abstract}

Keywords: cadmium toxicity; membrane transport; tissue tolerance; NRAMP; IRT; MTP; non-selective cation channel

\section{Cd Toxicity as an Issue}

\subsection{Cadmium in Soils}

Cadmium (Cd), a non-essential metal element for people and plants, is widely present in soils in Europe, China, Japan, and America [1]. The origin of cadmium can be divided into two types; one is from natural sources, the other one is of anthropogenic origin [2]. While cadmium is also present in the air and water, most of it eventually goes to the soil. Mineral oil and heavy metals are the main pollutants causing soil contamination, accounting for about $60 \%$. In nature, $\mathrm{Cd}$ is released into the environment through rivers and the atmosphere, mainly from weathering of soil parent material and volcanic activities, at an estimated rate of about 820 metric tons per year [3,4]. In contrast, anthropogenic Cd emissions are more serious, accounting for 8000 to 10,000 $\mathrm{mt}$ per year [5]. The major sources of anthropogenic $\mathrm{Cd}$ are from cadmium-related manufacturing, application of chemical fertilizers, contaminated sewage sludge and waste water, sewage effluents, and agricultural run-offs [6]. Cadmium migrates into the surrounding soil and atmosphere through solid waste combustion. Compared with urban soils, the content of cadmium in agricultural soil is relatively low [7]. However, due to the intensive use of phosphate fertilizer or leakage of factory sewage, Cd 
accumulation in agricultural soils is becoming a major issue. Cadmium is of a particular concern for plants, because it accumulates in leaves in high quantities, which can be 10-500 times higher than in plants grown in non-polluted environments, and may then enter the food chain by being eaten by animals or humans [8]. The ability of plants to absorb cadmium mainly depends on the concentration of soil $\mathrm{Cd}$ and plant ability of accumulation and translocation, and is also affected by $\mathrm{pH}$, temperature, and redox potential, as well as by concentrations of other elements and soil organic matter [9]. For example, excessive use of nitrogen and phosphate fertilizer in many areas of China led to increased soil acidification, while acidic soil accelerates the absorption of cadmium by plants [10]. Drought stress may also increase the rate of cadmium uptake 2-3-fold, compared with non-stressed conditions [11,12]. As described in Section 3.1, Cd uptake by plant roots shares the same pathway with zinc ( $\mathrm{Zn})$. Zn is an essential micronutrient and usually accompanies $C d$ with a ratio of 100:1 in most natural systems and anthropogenic environments [13-15]. Due to their similar geochemistry, $\mathrm{Cd}$ and $\mathrm{Zn}$ interactions are often of a synergistic nature. However, Cd toxicity is almost 10 times higher than that of $\mathrm{Zn}[16,17]$, and $\mathrm{Cd}$ is not required for plant growth and development, while $\mathrm{Zn}$ is considered essential for many metabolic functions.

\subsection{Cadmium Toxicity: Health Implications}

Most studies have shown that excessive cadmium accumulation leads to kidney dysfunction and lung damage. Cadmium is also a carcinogen that can cause kidney cancer and breast canceranemia. Other negative health effects include heart failure, hypertension, cerebral infarction, proteinuria, eye cataract formation, osteoporosis, emphysema, and renal insufficiency $[18,19]$. For example, the average weekly cadmium accumulation in Japan during the 1980s to 2000s was up to $4 \mathrm{mg}$ Cd per kilogram of body weight [20]; this has resulted in an outbreak of the Itai-Itai disease caused by Cd contamination in rice in the river basin of Toyama [6,21]. In a study on rats, a high level of lipid peroxidation was observed under the continued oral application of $3.5 \mathrm{mg} \cdot \mathrm{kg}^{-1}$ of $\mathrm{Cd}$, resulting in a high MDA level in liver, kidney, and serum [22]. Acute $\mathrm{Cd}$ treatments at higher doses resulted in a massive and rapid hepatic necrosis [23]. Cadmium accumulates in the human body mainly through the food chain, and most food comes from edible parts or seeds of crops [24]. An estimated $98 \%$ of cadmium intake comes from terrestrial foods, only $1 \%$ from aquatic foods, and $1 \%$ from cadmium in a drinking water [25]. Plant foods are generally considered to be the main source of $\mathrm{Cd}$ exposure in the population, and grains account for a large proportion of the total dietary intake. Wheat and rice are the major food crops for the global population [26,27]. Both species can easily absorb cadmium from the soil and accumulate it in grains [28,29]. In China, the average intake of cadmium for the general population more than doubled between 1990 and 2015 [30,31]. Of a specific concern is also Cd accumulation in leafy vegetables. Lettuce (Lactuca sativa L.) and endive (Cichorium endivia L.) are two important salad leafy vegetables; both may accumulate significant amounts of $\mathrm{Cd}$ in edible parts that can then enter the food chain. In these species, some studies have reported Cd contents of up to $9 \mathrm{mg} \cdot \mathrm{kg}^{-1}$ in their leaves, fourfold higher than that in roots and 20-30-fold higher than the actual Cd content in the soil (Table 1) [32,33]. Thus, preventing excessive accumulation of $\mathrm{Cd}$ in grains and leafy vegetables is critical for population health [34].

Table 1. Cd content in leafy vegetable plants (selected examples).

\begin{tabular}{|c|c|c|c|}
\hline Leafy Vegetable Species & $\begin{array}{c}\text { Range of Cd in Shoot } \\
\left(\mathrm{mg} \cdot \mathrm{kg}^{-1}\right)\end{array}$ & $\begin{array}{c}\text { Mean or Range of Cd in Soil } \\
\left(\mathrm{mg} \cdot \mathrm{kg}^{-1}\right)\end{array}$ & Reference \\
\hline Lactuca sativa $\mathrm{L}$. & 5.8 to 9.1 & 0.12 to 0.31 & Baldantoni et al. [32] \\
\hline Cichorium endivia L. & 0.61 to 3.80 & 0.13 to 0.51 & Baldantoni et al. [32] \\
\hline Brassica pekinensis L. & 1.05 to 3.51 & 2.42 & Wang et al. [33] \\
\hline
\end{tabular}




\subsection{Cadmium Impact on Plant Growth and Performance}

Cadmium causes a wide range of deleterious effects on plants, affecting plant metabolism and causing oxidative stress, nutrient uptake disturbance, and even plant death (Figure 1 ; [35]). At the whole-plant level, symptoms of Cd toxicity include growth delay, leaf chlorosis, and inhibition of photosynthesis and respiration [36]. Cd can impair plant development and growth by interfering with biochemical and physiologically related signaling pathways, such as affecting photosynthesis by interfering with photosynthetic electron transport, resulting in decreased chlorophyll content and stomatal conductance [37]. Moreover, the inhibition of root Fe(III) reductase induced by Cd led to $\mathrm{Fe}(\mathrm{II})$ deficiency, and it seriously affected photosynthesis [38]. Cadmium also changes membrane permeability, leading to a decrease in water content and affecting water balance [39].

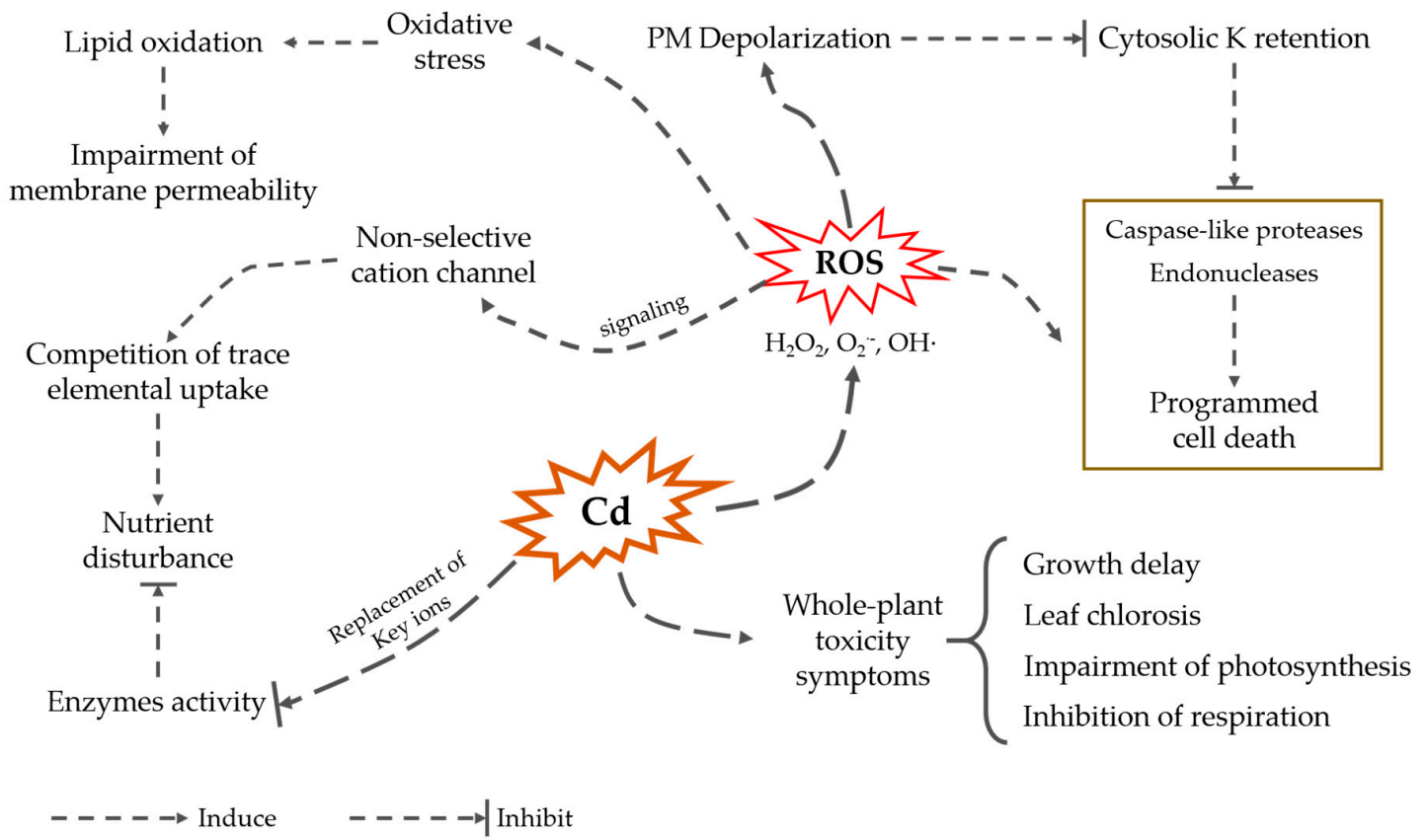

Figure 1. Cadmium effect on plant metabolism and growth.

Cadmium is a non-essential element; thus, plants have not developed a specialized uptake system for its absorption. Instead, $\mathrm{Cd}$ enters plants and is transported across various membranes by other metal transporters [40-43] or non-selective cation channels [44,45]. This results in a competition with acquisition of some essential metals. In addition, cadmium can also replace ions on the active sites of some enzymes, thus disrupting their activity and absorption of essential nutrients [46].

Cadmium also induces depolarization of the root cell plasma membrane, thus reducing the driving force for cation uptake (e.g., potassium). Potassium plays a key role in determining the fate of cells. In both mammalian [47] and plant $[48,49]$ systems, high cytosolic $\mathrm{K}^{+}$concentrations are required to suppress the activity of caspase-like proteases and endonucleases and, hence, prevent programmed cell death (PCD). Therefore, it could be envisaged that when cadmium ions affect the absorption and efflux of potassium, the imbalance of potassium ions in the cytoplasm will be caused, thus activating the cell PCD process.

The toxicity threshold for $\mathrm{Cd}$ in plants varies between plant species. Cd concentration in grains has been found to increase proportionally to the total $\mathrm{Cd}$ content in soils, and 0.3 and $0.1 \mathrm{mg} \cdot \mathrm{kg}^{-1}$ levels are considered as a likely threshold for barley and wheat, respectively [14]. Necrosis symptoms can be observed in tomato when grown in half-strength Hoagland solution containing $10 \mu \mathrm{M} \mathrm{Cd}$ for two weeks [50]. At the same time, in some hyperaccumulator species concentrations of $\mathrm{Cd}$ in some tissues may exceed these values by several orders of magnitude (e.g., $15,000 \mathrm{mg} \cdot \mathrm{kg}^{-1}$ in the pith tissue in Sedum alfredii; [51]). 


\section{Current Trends in Breeding Programs}

Given the importance of $\mathrm{Cd}$ toxicity issue for human health, the ideal solution for this problem would be via remediation of contaminated soils and preventing further anthropogenic-driven $\mathrm{Cd}$ contamination. However, achieving this goal may require a significant amount of time and orchestrated efforts and therefore can be considered as strategic only. An immediate solution may come through biological/genetic means, by creating cultivars with minimal, or no, $\mathrm{Cd}$ accumulation. Numerous attempts have been made to understand the genetic basis of $\mathrm{Cd}$ transport and accumulation in plants, in order to reduce $\mathrm{Cd}$ load. Given that over $50 \%$ of all calories consumed in the human diet comes from three major cereal crops (rice, wheat, and maize), reduction of $\mathrm{Cd}$ allocation to cereal grain is considered as the most essential objective in the breeding programs. This implies understanding the modes controlling $\mathrm{Cd}$ transfer from the roots to the shoots, followed by their modification by genetic means. Rice (Oryza sativa L.) is the main food feeding more than half of the global population; thus, the majority of research was done on this cereal. During the last decade, a series of QTL (quantitative trait loci) associated with $\mathrm{Cd}$ transportation in rice has been reported. Here, six different QTLs were found to be associated with $\mathrm{Cd}$ concentration in shoots during the seedling stage [52-55]. Genetic and physiological investigations suggest that the major QTL detected on the long arm of chromosome 11 is responsible for the specific translocation of $\mathrm{Cd}$ from the roots to the shoots [52]. Chromosome 7 harbors several putative metal transporters encoding genes such as OsZIP8, OsHMA3, and OsNramp1 [42,56]. Three major QTL ( $q C C B R 1-1, q C C B R 4-2$, and $q C C B R 9-1$ ) associated with Cd concentration in brown rice and another one named $q C C M R 11-2$ in the milled rice explained more than $20 \%$ of the phenotypic variance respectively. These findings may potentially facilitate marker-assisted selection of rice varieties with low Cd accumulation in grain. It was shown that OsCDT1, OsCDT3, and OsCDT4 located on chromosome 6, 1, and 2, respectively, encode a Cys-rich peptide in rice. This peptide chelates $\mathrm{Cd}$ at the cellular surface and prevents its further trans-membrane transportation, resulting in less cytosolic accumulation of $\mathrm{Cd}$ [57]. Further investigation demonstrated a differential binding affinity responding to diverse metal among CDTs [58], suggesting a possible genetic solution for modification of selectivity for these toxic metals. Recently, a new QTL, qGCd7.1, associated with high Cd accumulation was detected as a new OsHMA3 allele [59]. However, this new allele was weak at both transcriptional and protein levels in the test genotypes compared with the fully functional OsHMA3 lines. Liu et al. [60] also reported that a QTL for grain Cd concentration located on chromosome 7 (GCC7), which is responsible for differential shoot and grain $\mathrm{Cd}$ accumulation, had a different promoter activity of OsHMA3 regulating the expression level in shoot and grain. Together, it is plausible that GCC7 has a capacity to interact with $q G C d 7.1$ regulating the $C d$ uptake. Using genome-wide association studies, Liu et al. [61] reported 17 QTLs associated with grain Cd concentration. Among them, a novel candidate gene encoding OsARM1, a MYB transcription factor, previously known as responsible for freezing tolerance [62-64], was predicted to respond to Cd stress. Overexpression of the Cd-induced MYB49 gene in Arabidopsis resulted in a significant increase in Cd accumulation [65]. MYB49 was also interacting with $\mathrm{ABI} 5$ which was up-regulated by $\mathrm{Cd}$-induced $\mathrm{ABA}$ accumulation, implicating $\mathrm{ABA}$ signaling in control of $\mathrm{Cd}$ uptake and accumulation in plants [65]. In addition, one significant QTL referring to seed cadmium concentration was identified and validated in the $\mathrm{F}_{6: 7}$ NILs in soybean [66]. This major QTL located on chromosome 9 was revealed to account for more than $50 \%$ of the genetic variation in RILs populations and contributed to a phenotype with low seed Cd concentration. Further, an effect of the Cda1 locus on seed Cd concentration was confirmed by utilization of marker-selected soybean genotypes with a significant separation between high and low $\mathrm{Cd}$ accumulation [67]. However, despite these findings, no major progress in developing cultivars with low $\mathrm{Cd}$-accumulating ability was achieved. The reasons for this are twofold. First, with so many QTLs reported, it is not practical to implement $\mathrm{Cd}$ tolerance traits without transferring some other undesirable genes. Second, at the physiological level, $\mathrm{Cd}$ transporters also operate as transporters of essential micronutrients such as $\mathrm{Fe}$, $\mathrm{Zn}$, or Mn. Thus, attempts to reduce $\mathrm{Cd}$ accumulations in plants may compromise their capacity for taking up these beneficial nutrients. 


\section{Molecular Mechanisms of Cd Uptake and Transport}

\subsection{Cd Uptake by Roots}

Plant cells have no Cd-selective transporter; hence, $\mathrm{Cd}$ uptake occurs through plasma membrane transporters involved in the uptake of other divalent cations, including $\mathrm{Ca}, \mathrm{Mg}, \mathrm{Fe}, \mathrm{Zn}, \mathrm{Mn}$, and $\mathrm{Cu}$ [68]. Most of studies in the field were conducted on rice [69-71]. Several families of transporters have been implied to be responsible for $\mathrm{Cd}$ accumulation (Figure 2).

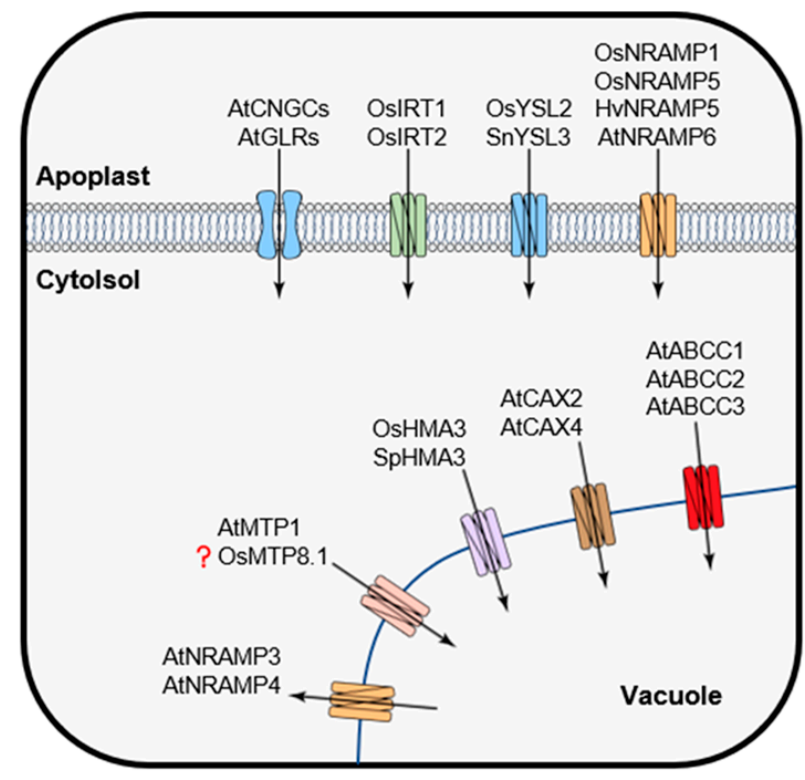

Cd uptake in root
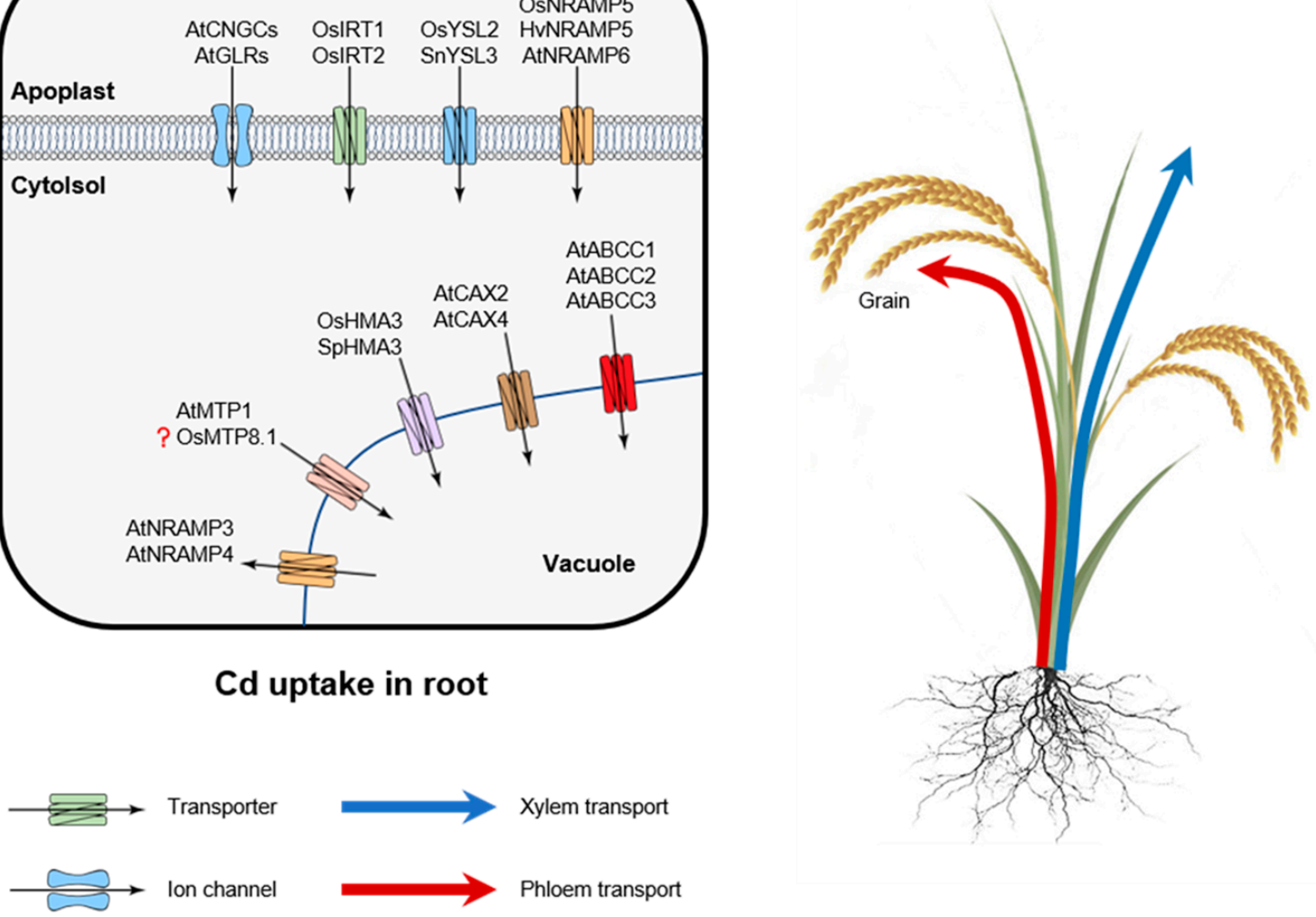

Figure 2. Uptake and intracellular compartmentation of cadmium in plant roots. Cd taken up by IRT1/2 (zinc/iron-regulated transporter-like protein), YSL2/3 (yellow stripe-like protein), and NRAMP1/5/6 (natural resistance-associated macrophage protein) transporters that are located at the plasma membrane of the root epidermis. Cd can be also transported into cells through non-selective cation (NSCC) channels such as CNGCs (cyclic nucleotide-gated channels) and GLRs (glutamate receptors). ABCC (ATP-binding cassette transporters), CAX (cation exchanger), HMA3 (metal-transporting ATPases), MTP1 (metal tolerance protein), and NRAMP3/4 mediate Cd transport and sequestration in the vacuole.

When present in ionic form, $\mathrm{Cd}$ uptake by plant roots could be mediated by three major transport systems [40,72-74]. One of them is NRAMP (natural resistance-associated macrophage protein). The best-known family members are OsNRAMP1, OsNRAMP5, and AtNRAMP6. Cd can be also taken via ZIP (zinc/iron-regulated transporter-like protein) transporters, such as AtIRT1 and TcZNT1/TcZIP4, and finally, by low-affinity calcium transporters (such as TaLCT1 in wheat). Cadmium can be also transported by transport systems mediating plant Fe uptake. Two distinct strategies are used by plants to accumulate Fe from soils. The first one relies on the uptake of a reduced form of $\mathrm{Fe}(\mathrm{II})$ (so-called Strategy I). Strategy II is only observed in grasses and implies uptake of chelated Fe(III). Here, $\mathrm{Fe}(\mathrm{III})$-phytosiderophore complexes (Fe(III)-PS) are taken into the root cells by yellow stripe 1 or yellow stripe-like 1 (YS1/YSL1) transporters identified in maize [75] and barley [76]. In chelated form, Cd may also be transported by YSL (yellow stripe-like 1) proteins such as OsYSL2 in rice and SnYSL3 
in Solanum nigrum [41,77]. Plants belonging to Strategy I have the ability to transport Cd across plasma membrane by the same mechanisms employed for $\mathrm{Fe}^{2+}$ transport. OsIRT1 was shown to be implicated in Cd influx, for example, upon reaeration of soil after flooding [42,78]. In Arabidopsis, the rate of root Cd uptake was much lower in atirt1 knockout mutant [79]. Ogawa et al. [78] showed that OsIRT1 and OsIRT2, two rice $\mathrm{Fe}^{2+}$ transporters, were also able to transport $\mathrm{Cd}$ when expressed in yeast. However, the role of these transporters for Cd uptake in planta seems to be rather minor in rice [73].

Of all the transporters above, NRAMP members have been demonstrated to be involved in numerous functions including uptake, translocation, intracellular transport, and detoxification of transition metals in many species [41,71,79-83]. In rice, OsNRAMP5, which plays a major role in $\mathrm{Mn}^{2+}$ uptake, may also represent a major route of $\mathrm{Cd}$ uptake by roots [73,82]. However, this view was challenged by Takahashi et al. [84] who showed rice mutants lacking functional OsNRAMP5 only showed a $\sim 20 \%$ reduction in root Cd content, while accumulating significant amounts of $\mathrm{Cd}$ in the shoot. In barley, HvNRAMP5, which shares 84\% identity with OsNRAMP5, can also mediate the uptake of Cd and Mn [83]. Interestingly, other orthologues of NRAMPs perform different specificity to NRAMP5. Among of them, OsNRAMP3 only has a capacity to transport Mn rather than Cd or Fe [85], while OsNRAMP1 can mediate uptake of trivalent Al ion [86]. In Arabidopsis, AtNRAMP3 and AtNRAMP4 can be functional to transport $\mathrm{Cd}^{2+}[87,88]$. AtNRAMP6 is also involved in intracellular $\mathrm{Cd}^{2+}$ transport [40]. The above results indicate that plants can transport cadmium through these low affinity metal transporters. However, the genetic variation affecting the selectivity of the transport for specific metals needs to be further investigated.

The summary of reported Cd transporters, their tissue-specific localization, and substrate specificity are given in the table below (Table 2).

Table 2. Transporters mediating cadmium uptake and translocation in plants.

\begin{tabular}{|c|c|c|c|}
\hline Transporter & Localization & Function/Substrate & Reference \\
\hline OsNRAMP1 & Roots and shoots (PM) & Influx of $\mathrm{Cd}, \mathrm{Al}$ & [42] \\
\hline OsZIP8 & Root (PM) & Influx of $\mathrm{Zn}, \mathrm{Fe}$ & [52] \\
\hline OsHMA3 & Roots (tonoplast) & Cd sequestration in root vacuoles & [52] \\
\hline SnYSL3 & $\begin{array}{l}\text { Vascular tissues and } \\
\text { epidermal cells of the } \\
\text { roots and stems (PM) }\end{array}$ & $\begin{array}{c}\text { Transport of nicotianamine } \\
\text { complexes containing } \mathrm{Fe}(\mathrm{II}), \mathrm{Cu}, \mathrm{Zn} \text {, } \\
\text { and } \mathrm{Cd}\end{array}$ & [41] \\
\hline OsYSL2 & $\begin{array}{l}\text { Vascular bundles, Roots } \\
\text { (PM) }\end{array}$ & $\begin{array}{l}\text { Influx of nicotianamine complexes } \\
\text { containing } \mathrm{Fe}(\mathrm{II}), \mathrm{Mn}, \mathrm{Ni} \text {, and } \mathrm{Cd}\end{array}$ & [77] \\
\hline OsIRT1 & Roots (PM) & Uptake of Fe, Zn, Mn, and Cd & [78] \\
\hline OsIRT2 & Roots (PM) & Uptake of $\mathrm{Fe}, \mathrm{Zn}, \mathrm{Mn}$, and $\mathrm{Cd}$ & [78] \\
\hline OsNRAMP5 & Roots (PM) & Uptake of Mn and Cd & [82] \\
\hline HvNRAMP5 & Roots (PM) & Uptake of Mn and Cd & [83] \\
\hline OsNRAMP3 & $\begin{array}{l}\text { Vascular bundles, roots, } \\
\text { leaves (tonoplast) }\end{array}$ & Uptake of Mn & [85] \\
\hline AtNRAMP3 & $\begin{array}{l}\text { Vascular bundles, roots, } \\
\text { leaves (tonoplast) }\end{array}$ & Efflux of Fe and Cd & {$[87,88]$} \\
\hline AtNRAMP4 & $\begin{array}{l}\text { Vascular bundles, roots, } \\
\text { leaves (tonoplast) }\end{array}$ & Efflux of Fe and Cd & {$[87,88]$} \\
\hline AtNRAMP6 & Roots, young leaves (PM) & Influx of Mn, & [40] \\
\hline AtCNGCs & Roots (PM) & Transporter for multiple cations & [89-92] \\
\hline AtGLRs & Roots (PM) & Transporter for multiple cations & {$[89,90,93-96]$} \\
\hline AtMTP1 & $\begin{array}{l}\text { Roots and leaves } \\
\text { (tonoplast) }\end{array}$ & Transporter for $\mathrm{Zn}$ and $\mathrm{Cd}$ & [97-100] \\
\hline
\end{tabular}


Table 2. Cont.

\begin{tabular}{|c|c|c|c|}
\hline Transporter & Localization & Function/Substrate & Reference \\
\hline CsMTP9 & $\begin{array}{l}\text { Roots endodermal cells } \\
\qquad(\mathrm{PM})\end{array}$ & Efflux of Mn and Cd & [101] \\
\hline OsMTP9 & Roots (PM) & Efflux of Mn & [102] \\
\hline OsMTP8.1 & Roots (tonoplast) & Sequestration of Mn into vacuoles & [103] \\
\hline TgMTP1 & $\begin{array}{l}\text { Roots and leaves } \\
\text { (tonoplast) }\end{array}$ & Transporter for $\mathrm{Zn}$ and $\mathrm{Cd}$ & [104] \\
\hline OsHMA5 & $\begin{array}{l}\text { Roots, vascular bundles } \\
\text { (tonoplast) }\end{array}$ & Loading of $\mathrm{Cu}$ in xylem & [105] \\
\hline AtHMA2 & $\begin{array}{l}\text { Roots, vascular tissue } \\
\text { (PM) }\end{array}$ & Delivery of $\mathrm{Zn}$ and $\mathrm{Cd}$ to xylem & {$[106,107]$} \\
\hline AtHMA4 & $\begin{array}{l}\text { Roots, vascular tissue } \\
(\mathrm{PM})\end{array}$ & Delivery of $\mathrm{Zn}$ and $\mathrm{Cd}$ to xylem & {$[106,107]$} \\
\hline OsLCT1 & $\begin{array}{l}\text { Leaves, nodes, phloem } \\
\text { parenchyma (PM) }\end{array}$ & Efflux of $\mathrm{Cd}, \mathrm{Ca}, \mathrm{Mg}$, and $\mathrm{Mn}$ & {$[74,108]$} \\
\hline AtABCC1 & $\begin{array}{l}\text { Roots and shoots } \\
\text { (tonoplast) }\end{array}$ & Uptake of PCs & [109] \\
\hline AtABCC2 & $\begin{array}{l}\text { Roots and shoots } \\
\text { (tonoplast) }\end{array}$ & Uptake of PCs & [109] \\
\hline AtABCC3 & $\begin{array}{l}\text { Roots and shoots } \\
\text { (tonoplast) }\end{array}$ & Uptake of PCs & [110] \\
\hline AhHMA3 & Roots, shoots (tonoplast) & Sequestration of $\mathrm{Zn}$ into vacuoles & [111] \\
\hline AtHMA3 & $\begin{array}{l}\text { Vascular tissues } \\
\text { (tonoplast) }\end{array}$ & Transport of $\mathrm{Zn}, \mathrm{Co}, \mathrm{Pb}$, and $\mathrm{Cd}$ & {$[112,113]$} \\
\hline SpHMA3 & Roots, shoots (tonoplast) & Sequestration of $\mathrm{Cd}$ into vacuoles & {$[114]$} \\
\hline AtCAX2 & Roots (tonoplast) & Vacuolar Cd, Zn, and Mn transport & {$[115,116]$} \\
\hline AtCAX4 & Roots (tonoplast) & Vacuolar Cd, Zn, and Mn transport & {$[115,116]$} \\
\hline
\end{tabular}

In the roots of a halophytic plant Suaeda salsa, $\mathrm{Cd}^{2+}$ influx was inhibited by $\mathrm{Ca}^{2+}$ uptake blockers. Higher plants lack $\mathrm{Ca}^{2+}$-selective channels [90], and $\mathrm{Ca}^{2+}$ uptake in plants is believed to occur mainly via non-selective cation (NSCC) channels [89]. Thus, these results suggest that some $\mathrm{Cd}^{2+}$ can be transported into cells through NSCC. The molecular nature and mechanisms of regulation of Cd uptake via NSCC remain elusive. Altogether, Arabidopsis genome harbors 40 NSCC channels from two major groups; 20 of these channels are classified as "cyclic nucleotide-gated channels" (CNGC), and the other 20 as "glutamate receptors" [90]. The specific roles each of these members in Cd uptake require investigation.

\subsection{Long-Distant Cd Transport}

Once taken by the root, $\mathrm{Cd}$ is then loaded into the xylem to be transported to the shoot. $\mathrm{Cd}$ translocation via the xylem is a key determinant of variation in grain $\mathrm{Cd}$ accumulation. The differences in the root-to-shoot $\mathrm{Cd}$ translocation rates of cultivars of $O$. sativa ssp. indica (high Cd-accumulating) and O. sativa ssp. japonica (low $\mathrm{Cd}$-accumulating) rice explain the genotypic variation in $\mathrm{Cd}$-accumulation observed in these two subspecies [26]. This translocation is mostly a function of retention in roots and xylem loading activity. The cation diffusion facilitator (CDF) family, otherwise known as the metal tolerance protein (MTP) family in plants, is believed to play an essential role in this process (Figure 3A). The MTPs/CDFs possess an ability to transport multiple ions and, depending on their selectivity, the 
members of MTP family are classified into three major clusters, including Zn-CDF, Mn-CDF, and Zn/Fe-CDF [97-100,117,118].
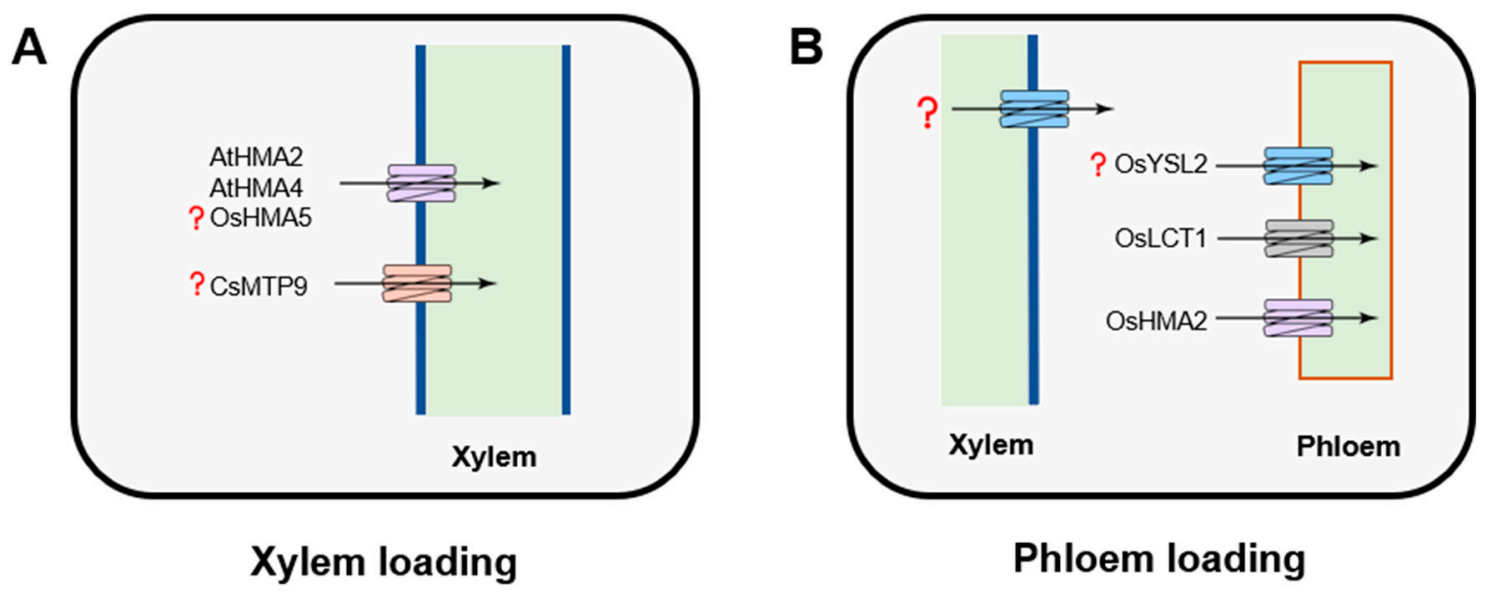

Figure 3. Transporters mediating xylem (A) and phloem (B) cadmium loading. HMA2 and LCT1 (low-affinity calcium transporter) are functioning in the translocation of $\mathrm{Cd}$ into the phloem. The major transporter that regulates xylem Cd loading is HMA2/4. The role of MTP9 in the long-distance Cd transport remains unclear.

Functionally, MTP members operate as efflux transporters. It was shown that CsMTP9, known as an efflux transporter for $\mathrm{Mn}$, rescued the Cd-hypersensitive phenotype when expressed in yeast, resulting from strengthened $\mathrm{Cd}^{2+}$ efflux activity [101]. However, OsMTP9 does not have a capacity to transport Cd, suggesting a different unidentified transporter involved in this pathway [102]. In rice, OsMTP8.1 has been described as a vacuolar Mn-specific transporter, but its role in Cd uptake has not been evaluated [103]. In Arabidopsis, MTP1 has been described as a $\mathrm{Zn}^{2+} / \mathrm{H}^{+}$vacuolar transporter, which also showed a capacity to mediate Cd flux in Thlaspi goesingense [99,104]. Podar et al. [119] also reported that MTP1 is a $\mathrm{Zn}^{2+} / \mathrm{Co}^{2+}$-specific transporter, with a high affinity to $\mathrm{Zn}^{2+}$ when expressed in barley. Importantly, the structure-function analysis of MTP1 suggests that it is possible to increase the selectivity of AtMTP1 towards Zn by modifying a five-residue sequence within the MTP1 N-segment of the His-rich intracytoplasmic loop. This His-rich loop was suggested to be a determinant of the identity of the metal ion [100].

$\mathrm{P}_{1 \mathrm{~B}}$-type heavy metal-transporting ATPases (HMAs) transport heavy metals $\left(\mathrm{Cu}^{+}, \mathrm{Cu}^{2+}, \mathrm{Zn}^{2+}\right.$, $\left.\mathrm{Co}^{2+}, \mathrm{Cd}^{2+}, \mathrm{Pb}^{2+}\right)$ across membranes are present in most organisms and crucial for the cellular metal homeostasis. Most of them are not fully characterized. OsHMA5 has also been localized to the root pericycle cells and xylem but seems to have more affinity to copper rather than other metal ions [105]. In Arabidopsis, HMA2 and HMA4 are considered to load Cd and Zn into the xylem [106,107]. The latest study on the identification of mutations from amino acids of HMA4 transmembrane helices (TMs) indicated a potential solution to alter the function of this transporter in Arabidopsis hma2/hma4 double mutant. The transporter with substitution of E169 and K667 by Ala residues can still transport $\mathrm{Cd}^{2+}$ as the native protein, while $\mathrm{Zn}^{2+}$ transport is completely silenced [107].

Although the long-distant transport via phloem is crucial for $\mathrm{Cd}$ accumulation in seeds and grains, the mechanistic basis of this process is poorly understood (Figure 3B). So far, OsHMA2 has been described to function in intervascular $\mathrm{Cd}$ delivery to developing tissues in the uppermost node of rice [85]. The loss of OsHMA2 function in insertion mutants results in decreased leaf and grain $\mathrm{Cd}$ concentrations [120]. An increase in Cd tolerance in rice and reduction of $\mathrm{Cd}$ accumulation in grains can be observed in the overexpression lines of OsHMA3 [54,121]. Another transporter that mediates phloem-based Cd distribution is LCT1 (low-affinity cation transporter 1) [74,108]. OsLCT1 encodes a plasma membrane-localized protein, which is mainly expressed in phloem parenchyma cells in leaf blades and nodes during the reproductive stage [108]. OsLCT1 transcript level is strongly 
upregulated during the reproductive stage in rice, and a decrease in Cd concentration in grains can be observed in its oslct1 knockdown line [74]. OsYSL2, an orthologue of ZmYSL1, is mainly expressed in parenchyma, suggesting a potential capacity to transport $\mathrm{Cd}$ in phloem [77]. At this stage, given the limited knowledge on molecular mechanisms of phloem loading, LCT1 and HMA2 are the likely candidate genes for further modification to restrain the translocation of $\mathrm{Cd}$, particularly into grain in cereal crops.

\section{Tissue Tolerance Mechanisms}

To minimize the toxicity of $\mathrm{Cd}$ exposure and its accumulation, plants have evolved various detoxification mechanisms to surmount the adverse effects. Sequestration in root vacuoles has been demonstrated as the major process limiting the translocation of $\mathrm{Cd}$ to shoots and seeds [54,122]. As the largest organelle inside the mature plant cell, vacuole is an important reservoir of ions and metabolites and is crucial for the detoxification process as well as normal cell development [123,124].

$\mathrm{Cd}$ has a strong affinity for thiol-containing molecules such as cysteine, glutathione, and phytochelatins (PCs). Phytochelatins react with heavy metal ions by glutathione S-transferase catalyzation in the cytosol, and afterwards, they are sequestered into the vacuole for degradation. In sequestration into vacuoles, ATP-binding cassette transporters mediate influx of PC-metal (loid) complexes. In Schizosaccharomyces pombe, the first ABC transporter HMT1 located at the tonoplast was reported to aid transporting PC-Cd complexes formed in the cytosol [125-127]. A functional homolog of HMT1 has been then reported in Caenorhabditis elegans and Drosophila [128,129]. In Arabidopsis, ABCC1 and ABCC2 have been identified as the main transporters mediating PC uptake into vacuoles [109,130]. $\mathrm{Cd}$ staining experiments showed that $\mathrm{Cd}$ was mainly present in the cytosol in abcc1abcc2 double mutant, whereas almost all $\mathrm{Cd}$ has been compartmentalized in the vacuoles of the wild type [131]. Orthologs of AtABCC1 have been identified in numerous grasses including rice, maize, and barley. In barley, a vacuole kinetic analysis also suggests that this transport mechanism is conserved across species [132]. AtABCC3 was also shown to play an important role on Cd tolerance. Plants overexpressing AtABCC3 showed Cd-tolerant phenotypes, while a mutant defective in atabcc3 was more sensitive to Cd stress. The function of AtABCC3 is highly dependent on PCs. When AtABCC3 was expressed in the cad1-3 mutant (defective in PC synthesis) or AtABCC3-overexpressing plants were subjected to BSO (an PC biosynthesis inhibitor), the Cd-tolerant phenotype disappeared [110].

In contrast to ABCCs, for which $\mathrm{Cd}$ transport is coupled to phytochelatins, the heavy metal-transporting ATPases (HMAs), cation diffusion facilitator (CDF), and $\mathrm{Ca}^{2+}$ exchangers transport the ionic form of $\mathrm{Cd}\left(\mathrm{Cd}^{2+}\right)$. P1B-type ATPases have also been shown to play a key role on sequestering $\mathrm{Cd}$ in root vacuoles [54]. Of interest is the fact that OsHMA3 seems to be highly specific for Cd, while the Arabidopsis halleri HMA3 has a preference for Zn. However, the A. thaliana HMA3 shows broad substrate specificity being able to transport $\mathrm{Co}, \mathrm{Pb}, \mathrm{Cd}$, and $\mathrm{Zn} \mathrm{[111,112].} \mathrm{OsHMA3,} \mathrm{a} \mathrm{vacuolar}$ P1B-type ATPase was found to contribute $85.6 \%$ of the variance in Cd content between low-and high-cadmium accumulation varieties of rice [54]. The important role of OsHMA3 as controlling shoot Cd accumulation was demonstrated by QTL analysis of low and high Cd-accumulating rice cultivars [133]. In Arabidopsis, the function of HMA3 was attributed to limiting long-distance transport of $\mathrm{Cd}$ from the root to the shoot as this transporter is predominantly expressed in the root and thus operates in its sequestration here [113]. The crucial role of HMA3 for plants' ability to handle high concentrations of $\mathrm{Cd}$ in shoots is also broadly reported for hyperaccumulating species. Working with hyperaccumulating Sedum alfredii species, Zhang et al. [134] reported high level of SaHMA3h expression leading to efficient detoxifying ability in this species. S. alfredii plants also had a larger number of gene copies as compared with its non-hyperaccumulator ecotype. In S. plumbizincicola shoots, particularly in young leaf cells, SpHMA3 is critical for Cd detoxification and acts by sequestering Cd into vacuoles [114]. Some transporters like CAXs and NRAMPs, which are tonoplast-localized, also play a role in Cd tolerance [135]. Most of the CAXs are $\mathrm{Ca}^{2+}$ specific, but in Arabidopsis, AtCAX2 and AtCAX4 were shown to have the ability to transport other metals like Cd, Zn, and Mn $[115,116]$. A 
heterologous overexpression of SaCAX2a from hyperaccumulating S. alfredii plants in tobacco resulted in improved Cd tolerance [134]. Likewise, the atnramp3atnramp4 double knockout mutant exhibits increased sensitivity to $\mathrm{Cd}$ [136] but also displayed Fe deficiency symptoms. NRAMP3 and NRAMP4 are also believed to be involved in the remobilization of essential metals by exporting them across the tonoplast membrane from the vacuole [137].

Besides those divalent cation transporters functioning in cellular sequestration, organic acids are considered to have an involvement in detoxification mechanisms. Of interest is that organic acids such as citric, malic, and carboxylic acids may stabilize $\mathrm{Cd}^{2+}$ in a complex form. The root hair of $\mathrm{Cd}$ hyperaccumulator Thlaspi caerulescens contains high levels of citric and malonic acids that distribute high Cd levels in cell walls, ensuring that plants can tolerate Cd-induced stress [138]. In leaves of the $\mathrm{Cd}$ hyperaccumulator Solanum nigrum, both acetic and citric acid bind with $\mathrm{Cd}$, enabling the formation of Cd-organic acid complex for chelation [139]. Ehsan et al. [140] found that citric acid in culture solution forms a citric complex of $\mathrm{Cd}$ that can be easily translocated from the roots to shoots of Brassica napus without any toxicity occurrence, thus peaking its phytoextraction potential. The secretion of malic and oxalic acids in tissues of Agrogyron elongatum grown in the nutrient medium was positively correlated with peak $\mathrm{Cd}$ levels and tolerance mechanisms for coping with $\mathrm{Cd}$ toxicity [141]. In addition, the binding affinity of organic acids to $\mathrm{Cd}$ forms a complex with $\mathrm{Cd}^{2+}$ thus reducing the availability of free toxic $\mathrm{Cd}^{2+}$ in the growth medium and alleviates phytotoxicity induced by excess $\mathrm{Cd}$.

\section{Conclusions and the Way Forward}

$\mathrm{Cd}$ has long been recognized as a major health threat to humans. It represents one of the most toxic substances released into the environment, and practically all human populations are environmentally exposed to $\mathrm{Cd}$, mostly through plant-derived food. Thus, the ability to regulate $\mathrm{Cd}$ loading into the xylem and its delivery to the shoot with a transpiration stream in leafy vegetables is critical to avoid $\mathrm{Cd}$ entering the food chain. Equally important is the prevention of $\mathrm{Cd}$ being accumulated in cereal grains (by phloem-based retranslocation mechanism). While a significant progress has been made in revealing the molecular nature of transporters mediating $\mathrm{Cd}$ uptake and transport across cellular membranes, reducing $\mathrm{Cd}$ accumulation in plants is complicated by the fact that most known $\mathrm{Cd}$ transporters also operate in the transport of essential nutrients such as $\mathrm{Zn}, \mathrm{Fe}, \mathrm{Mn}$, or $\mathrm{Cu}$. Thus, the real progress in the field may be only achieved if transport of these nutrients and $\mathrm{Cd}$ is uncoupled. This calls for more studies dealing with structure-function relations of various transporters isoforms. In this context, Kawachi et al. $[98,100]$ conducted a structure-function analysis of Arabidopsis MTP1 transporter from the cation diffusion facilitator family. Based on the crystal structure of the Escherichia coli and using site-directed mutagenesis, they showed that Ala substitution of either Asn258 in TM5 or Ser101 in TM2 reduced AtMTP1 selectivity for $\mathrm{Zn}^{2+}$ in yeast. They also showed that deletions in $\mathrm{N}$-terminal and His-rich intra-molecular cytosolic domains and mutations of single residues flanking the transmembrane pore or participating in intra- or inter-molecular domain interactions selectively affected yeast's ability to accumulate $\mathrm{Co}$ and $\mathrm{Cd}$ [100]. Thus, uncoupling of Cd transport from transport of essential micronutrients is technically possible and just required some more orchestrated efforts. The major hurdle in this process is a high tissue specificity of transporter operation. Two tissues are of a specific importance in this context. The first one is a xylem parenchyma in plant roots, a major "controller" of Cd loading into the xylem and its transport to the shoot. The second one is a phloem tissue that operates in the last step of the metal transport from mature leaves (where $\mathrm{Cd}$ is delivered) to the developing grains. Ion remobilization from leaves and transport to developing grains is currently terra incognita, hinting at many unexploited ways to improve crops genetically. Another promising and currently underexplored avenue is to understand the role of non-selective cation channels in Cd uptake and reveal mechanisms of their regulation. Arabidopsis genome harbors 40 non-selective cation channels (NSCC) [90]; 20 of them belong to ionotropic "glutamate receptor-like" (GLR) family. Other plant families also have over 10 GLR members in their genomes [93-96]. GLRs are believed to be tetramers consisting of different subunits, with preferential expression in root tissues [142]. The other 
20 channels are classified as "cyclic nucleotide-gated channels" (CNGC). CNGCs are structurally similar to members of the superfamily of six transmembrane "Shaker-like" pore-loop ion channels [91,92]. All these channels need to be functionally characterized for their ability to uptake $\mathrm{Cd}^{2+}$ in functional (MIFE or patch-clamp electrophysiology) assays and then validated in genetic studies.

Author Contributions: Conceptualization, S.S. and X.H.; data collection, X.H., Q.W., S.D. and S.S.; writing-X.H., S.D., Q.W., and S.S.; critical revision, S.S., X.H. and M.Y.; funding acquisition, M.Y. and S.S. All authors have read and agreed to the published version of the manuscript.

Funding: This research was funded by National Natural Science Foundation of China $(31672228,31870249)$, the Science and Technology Department of Guangdong Province (2018A050506085, 163-2018-XMZC-0001-05-0049), and the Science and Technology Bureau of Foshan (20161201010027).

Conflicts of Interest: The authors declare no conflict of interest.

\section{References}

1. Panos, P.; Marc, V.L.; Yusuf, Y.; Luca, M. Contaminated sites in Europe: Review of the current situation based on data collected through a European network. J. Environ. Public Health 2013, 2013, 158764.

2. Alloway, B.J. Heavy Metals in Soils: Trace Metals and Metalloids in Soils and Their Bioavailability; Springer: Dordrecht, The Netherlands, 2013.

3. Cook, M.E.; Morrow, H. Anthropogenic sources of cadmium in Canada. In National Workshop on Cadmium Transport into Plants; Canadian Network of Toxicology Centres: Ottawa, ON, Canada, 1995.

4. Hayat, M.T.; Nauman, M.; Nazir, N.; Ali, S.; Bangash, N. Environmental hazards of cadmium: Past, present, and future. In Cadmium Toxicity and Tolerance in Plants. From Physiology to Remediation; Hasanuzzaman, M., Prasad, M.N.V., Fujita, M., Eds.; Academic Press: London, UK, 2019; pp. 163-183.

5. World Health Organisation (WHO). Environmental Health Criteria 134-Cadmium International Programme on Chemical Safety (IPCS) Monograph; World Health Organization: Geneva, Switzerland, 1992.

6. Xue, D.W.; Jiang, H.; Deng, X.X.; Zhang, X.Q.; Wang, H.; Xu, X.B.; Hu, J.; Zeng, D.; Guo, L.; Qian, Q. Comparative proteomic analysis provides new insights into cadmium accumulation in rice grain under cadmium stress. J. Hazard. Mater. 2014, 280, 269-278. [CrossRef]

7. Clemens, S.; Ma, J.F. Toxic heavy metal and metalloid accumulation in crop plants and foods. Annu. Rev. Plant Biol. 2016, 67, 489-512. [CrossRef]

8. Zu, Y.; Li, Y.; Chen, J.; Chen, H.Y.; Li, Q.; Schratz, C. Hyper accumulation of $\mathrm{Pb}, \mathrm{Zn}$ and $\mathrm{Cd}$ in herbaceous grown on lead-zinc mining area in Yunnan, China. Environ. Int. 2005, 1, 755-762.

9. Sanita, D.T.L.; Gabbrielli, R. Response to cadmium in higher plants. Environ. Exp. Bot. 1999, 41, 105-130. [CrossRef]

10. Zhao, K.L.; Fu, W.J.; Ye, Z.Q.; Zhang, C.S. Contamination and spatial variation of heavy metals in the soil-rice system in Nanxun County, Southeastern China. J. Environ. Res. Public Health 2015, 12, 1577-1594. [CrossRef] [PubMed]

11. Bauddh, K.; Singh, R.P. Growth, tolerance efficiency and phytoremediation potential of Ricinus communis (L.) and Brassica juncea (L.) in salinity and drought affected cadmium contaminated soil. Ecotoxicol. Environ. Saf. 2012, 85, 13-22. [CrossRef]

12. Shi, G.; Xia, S.; Ye, J.; Huang, Y.; Liu, C.; Zhang, Z. PEG-simulated drought stress decreases cadmium accumulation in castor bean by altering root morphology. Environ. Exp. Bot. 2015, 111, 127-134. [CrossRef]

13. Demeyer, A.; Nkana, J.V.; Verloo, M.G. Characteristics of wood ash and influence on soil properties and nutrient uptake: An overview. Bioresour. Technol. 2001, 77, 287-295. [CrossRef]

14. Kabata-Pendias, A. Trace Elements in Soils and Plants, 4th ed.; CRC Press: Boca Raton, FL, USA, 2011.

15. Smith, S.R. A critical review of the bioavailability and impacts of heavy metals in municipal solid waste composts compared to sewage sludge. Environ. Int. 2009, 35, 142-156. [CrossRef]

16. De Oliveira, V.H.; Tibbett, M. Cd and $\mathrm{Zn}$ interactions and toxicity in ectomycorrhizal basidiomycetes in axenic culture. PeerJ 2018, 6, e4478. [CrossRef] [PubMed]

17. Johansen, J.L.; Rønn, R.; Ekelund, F. Toxicity of cadmium and zinc to small soil protists. Environ. Pollut. 2018, 242, 1510-1517. [CrossRef] [PubMed]

18. Godt, J.; Scheidig, F.; Grosse-Siestrup, C.; Esche, V.; Brandenburg, P.; Reich, A.; Groneberg, D.A. The toxicity of cadmium and resulting hazards for human health. J. Occup. Med. Toxicol. 2016, 1, 22. [CrossRef] [PubMed] 
19. Nawrot, T.; Plusquin, M.; Hogervorst, J.; Roels, H.A.; Celis, H.; Thijs, L.; Vangronsveld, J.; Van Hecke, E.; Staessen, J.A. Environmental exposure to cadmium and risk of cancer: A prospective populationbased study. Lancet Oncol. 2006, 7, 119-126. [CrossRef]

20. Tsukahara, T.; Ezaki, T.; Moriguchi, J.; Furuki, K.; Shimbo, S.; Matsuda-Inoguchi, N.; Ikeda, M. Rice as the most influential source of cadmium intake among general Japanese population. Sci. Total Environ. 2003, 305, 41-51. [CrossRef]

21. Inaba, T.; Kobayashi, E.; Suwazono, Y.; Uetani, M.; Oishi, M.; Nakagawa, H.; Nogawa, K. Estimation of cumulative cadmium intake causing Itai-itai disease. Toxicol. Lett. 2005, 159, 192-201. [CrossRef]

22. Kara, H.; Karatas, F.; Canatan, H.; Servi, K. Effects of exogenous metallothionein on acute cadmium toxicity in rats. Biol. Trace Elem. Res. 2005, 104, 223. [CrossRef]

23. Dudley, R.E.; Svoboda, D.J.; Klaassen, C.D. Acute exposure to cadmium causes severe liver injury in rats. Toxicol. Appl. Pharm. 1982, 65, 302-313. [CrossRef]

24. Touceda-González, M.; Brader, G.; Antonielli, L.; Ravindran, V.B.; Waldner, G.; Friesl-Hanl, W.; Corretto, E.; Campisano, A.; Pancher, M.; Angela, S. Combined amendment of immobilizers and the plant growth-promoting strain Burkholderia phytofirmans PsJN favours plant growth and reduces heavy metal uptake. Soil Biol. Biochem. 2015, 91, 140-150. [CrossRef]

25. Van Assche, F.J. A Stepwise Model to Quantify the Relative Contribution of Different Environmental Sources to Human Cadmium Exposure. In Proceedings of the 8th International Nickel-Cadmium Battery Conference, Prague, Czech Republic, 21-22 September 1998.

26. Clemens, S.; Aarts, M.G.M.; Thomine, S.; Verbruggen, N. Plant science: The key to preventing slow cadmium poisoning. Trends Plant Sci. 2013, 18, 92-99. [CrossRef]

27. Uraguchi, S.; Fujiwara, T. Rice breaks ground for cadmium free cereals. Curr. Opin. Plant Biol. 2013, 16, 328-334. [CrossRef] [PubMed]

28. Liu, F.; Liu, X.N.; Ding, C.; Wu, L. The dynamic simulation of rice growth parameters under cadmium stress with the assimilation of multi-period spectral indices and crop model. Field Crops Res. 2015, 183, 225-234. [CrossRef]

29. Song, W.E.; Chen, S.B.; Liu, J.F.; Chen, L.; Song, N.N.; Li, N.; Liu, B.V. Variation of Cd concentration in various rice cultivars and derivation of cadmium toxicity thresholds for paddy soil by species-sensitivity distribution. J. Integr. Agric. 2015, 14, 1845-1854. [CrossRef]

30. Chen, H.; Yang, X.; Wang, P.; Wang, Z.; Li, M.; Zhao, F.J. Dietary cadmium intake from rice and vegetables and potential health risk: A case study in Xiangtan, southern China. Sci. Total Environ. 2018, 639, 271-277. [CrossRef]

31. Song, Y.; Wang, Y.; Mao, W.; Sui, H.; Yong, L.; Yang, D.; Jiang, D.; Zhang, L.; Gong, Y. Dietary cadmium exposure assessment among the Chinese population. PLOS ONE 2017, 12, e0177978. [CrossRef]

32. Baldantoni, D.; Morra, L.; Zaccardelli, M.; Alfani, A. Cadmium accumulation in leaves of leafy vegetables. Ecotoxicol. Environ. Saf. 2016, 123, 89-94. [CrossRef]

33. Wang, J.; Yu, N.; Mu, G.; Shinwari, K.I.; Shen, Z.; Zheng, L. Screening for Cd-safe cultivars of Chinese cabbage and a preliminary study on the mechanisms of Cd accumulation. Int. J. Environ. Res. Public Health 2017, 14, 395. [CrossRef]

34. FAO Food and Agriculture Organization. ProdStat. Core Production Data Base, Core Production Data Base, Electronic Resource. 2012. Available online: http://faostat.fao.org/ (accessed on 11 October 2019).

35. Mohamed, A.A.; Castagna, A.; Ranieri, A.; Sanita di Toppi, L. Cadmium tolerance in Brassica juncea roots and shoots is affected by antioxidant status and phytochelatin biosynthesis. Plant Physiol. Biochem. 2012, 57, 15-22. [CrossRef]

36. Navarro-Leon, E.; Oviedo-Silva, J.; Ruiz, J.M.; Blasco, B. Possible role of HMA4a TILLING mutants of Brassica rapa in cadmium. Ecotoxicol. Environ. Saf. 2019, 180, 88-94. [CrossRef]

37. Hassan, M.J.; Zhang, G.; Zhu, Z. Influence of cadmium toxicity on plant growth and nitrogen uptake in rice as affected by nitrogen form. J. Plant Nutr. 2008, 31, 251-262. [CrossRef]

38. Alcantara, E.; Romera, F.J.; Canete, M.; De La Guardia, M.D. Effects of heavy metals on both induction and function of root Fe(III) reductase in Fe-deficient cucumber (Cucumis sativus L.) plants. J. Exp. Bot. 1994, 45, 1893-1898. [CrossRef]

39. Sharma, V.; Pant, D. Structural basis for expanding the application of bioligand in metal bioremediation: A review. Bioresour. Technol. 2018, 252, 188-197. [CrossRef] [PubMed] 
40. Cailliatte, R.; Lapeyre, B.; Briat, J.F.; Mari, S.; Curie, C. The NRAMP6 metal transporter contributes to cadmium toxicity. Biochem. J. 2009, 422, 217-228. [CrossRef] [PubMed]

41. Feng, S.; Tan, J.; Zhang, Y.; Liang, S.; Xiang, S.; Wang, H.; Chai, T. Isolation and characterization of a novel cadmium-regulated Yellow Stripe-Like transporter (SnYSL3) in Solanum nigrum. Plant Cell Rep. 2017, 36, 281-296. [CrossRef]

42. Takahashi, R.; Ishimaru, Y.; Senoura, T.; Shimo, H.; Ishikawa, S.; Arao, T.; Nakanishi, H.; Nishizawa, N.K. The OsNRAMP1 iron transporter is involved in Cd accumulation in rice. J. Exp. Bot. 2011, 62, 4843-4850. [CrossRef]

43. Wu, Z.L.; Yin, X.B.; Banuelos, G.S.; Lin, Z.Q.; Liu, Y.; Li, M.; Yuan, L.X. Indications of selenium protection against cadmium and lead toxicity in oilseed rape (Brassica napus L.). Front. Plant Sci. 2016, 7, 1875. [CrossRef]

44. Lindberg, S.; Landberg, T.; Greger, M. A new method to detect cadmium uptake in protoplasts. Planta 2004, 219, 526-532. [CrossRef]

45. Li, D.D.; Zhou, D.M. Toxicity and subcellular distribution of cadmium in wheat as affected by dissolved organic acids. J. Environ. Sci. 2012, 24, 903-911. [CrossRef]

46. Jasinski, M.; Sudre, D.; Schansker, G.; Schellenberg, M.; Constant, S.; Martinoia, E. Atosa1, a member of the abc1-like family, as a new factor in cadmium and oxidative stress response. Plant Physiol. 2008, 147, 719-731. [CrossRef]

47. Bortner, C.D.; Hughes, F.M.; Cidlowski, J.A. A primary role for $\mathrm{K}^{+}$and $\mathrm{Na}^{+}$efflux in the activation of apoptosis. J. Biol. Chem. 1977, 272, 32436-32442. [CrossRef]

48. Demidchik, V.; Cuin, T.A.; Svistunenko, D.; Smith, S.J.; Miller, A.J.; Shabala, S.; Sokolik, A.; Yurin, V. Arabidopsis root $\mathrm{K}^{+}$efflux conductance by hydroxyl radicals: Single-channel properties, genetic basis and involvement in stress-induced cell death. J. Cell Sci. 2010, 123, 1468-1479. [CrossRef] [PubMed]

49. Shabala, S. Physiological and cellular aspects of phytotoxicity tolerance in plants: The role of membrane transporters and implications for crop breeding for waterlogging tolerance. New Phytol. 2007, 190, 289-298. [CrossRef] [PubMed]

50. López-Millán, A.F.; Sagardoy, R.; Solanas, M.; Abadía, A.; Abadía, J. Cadmium toxicity in tomato (Lycopersicon esculentum) plants grown in hydroponics. Environ. Exp. Bot. 2009, 65, 376-385. [CrossRef]

51. Tian, S.; Lu, L.; Labavitch, J.; Yang, X.; He, Z.; Hu, H.; Sarangi, R.; Newville, M.; Commisso, J.; Brown, P. Cellular sequestration of cadmium in the hyperaccumulator plant species Sedum alfredii. Plant Physiol. 2011, 157, 1914-1925. [CrossRef]

52. Ueno, D.; Kono, I.; Yokosho, K.; Ando, T.; Yano, M.; Ma, J.F. A major quantitative trait locus controlling cadmium translocation in rice (Oryza sativa). New Phytol. 2009, 182, 644-653. [CrossRef]

53. Ueno, D.; Koyama, E.; Kono, I.; Ando, T.; Yano, M.; Ma, J.F. Identification of a novel major quantitative trait locus controlling distribution of Cd between roots and shoots in Rice. Plant Cell Physiol. 2009, 50, 2223-2233. [CrossRef]

54. Ueno, D.; Yamaji, N.; Kono, I.; Huang, C.F.; Ando, T.; Yano, M.; Ma, J.F. Gene limiting cadmium accumulation in rice. Proc. Natl. Acad. Sci. USA 2010, 107, 16500-16505. [CrossRef]

55. Yan, J.; Wang, P.; Wang, P.; Yang, M.; Lian, X.; Tang, Z.; Huang, C.; Salt, D.; Zhao, F.J. A loss-of-function allele of associated with high cadmium accumulation in shoots and grain of rice cultivars. Plant Cell Environ. 2016, 39, 1941-1954. [CrossRef]

56. Hu, D.; Sheng, Z.; Li, Q.; Chen, W.; Wei, X.; Xie, L.; Jiao, G.; Shao, G.; Wang, J.; Tang, S.; et al. Identification of QTLs associated with cadmium concentration in rice grains. J. Integr. Agric. 2018, 17, 1563-1573. [CrossRef]

57. Kuramata, M.; Masuya, S.; Takahashi, Y.; Kitagawa, E.; Inoue, C.; Ishikawa, S.; Youssefian, S.; Kusano, T. Novel cysteine-rich peptides from Digitaria ciliaris and Oryza sativa enhance tolerance to cadmium by limiting its cellular accumulation. Plant Cell Physiol. 2009, 50, 106-117. [CrossRef]

58. Xia, J.X.; Yamaji, N.; Ma, J.F. A plasma membrane-localized small peptide is involved in rice aluminum tolerance. Plant J. 2013, 76, 345-355. [CrossRef] [PubMed]

59. Sun, C.; Yang, M.; Li, Y.; Tian, J.; Zhang, Y.; Liang, L.; Liu, Z.; Chen, K.; Li, Y.; Lv, K.; et al. Comprehensive analysis of variation of cadmium accumulation in rice and detection of a new weak allele of OsHMA3. J. Exp. Bot. 2019, 70, 6389-6400. [CrossRef] [PubMed]

60. Liu, C.; Gao, Z.; Shang, L.; Yang, C.; Ruan, B.; Zeng, D.; Guo, L.; Zhao, F.; Huang, C.; Qian, Q. Natural variation in the promoter of OsHMA3 contributes to differential grain cadmium accumulation between indica and japonica rice. J. Integr. Plant Biol. 2009, 1672-9072. [CrossRef] [PubMed] 
61. Liu, X.; Chen, S.; Chen, M.; Zheng, G.; Peng, Y.; Shi, X.; Qin, P.; Xu, X.; Teng, S. Association study reveals genetic loci responsible for arsenic, cadmium and lead accumulation in rice grain in contaminated farmlands. Front. Plant Sci. 2009, 10, 61. [CrossRef] [PubMed]

62. Dai, X.; Xu, Y.; Ma, Q.; Xu, W.; Wang, T.; Xue, Y.; Chong, K. Overexpression of an R1R2R3 MYB gene, OsMYB3R-2, increases tolerance to freezing, drought, and salt stress in transgenic Arabidopsis. Plant Physiol. 2007, 143, 1739-1751. [CrossRef]

63. Ma, Q.; Dai, X.; Xu, Y.; Guo, J.; Liu, Y.; Chen, N.; Xiao, J.; Zhang, D.; Xu, Z.; Zhang, X.; et al. Enhanced tolerance to chilling stress in OsMYB3R2 transgenic rice is mediated by alteration in cell cycle and ectopic expression of stress genes. Plant Physiol. 2009, 150, 244-256. [CrossRef]

64. Lv, Y.; Yang, M.; Hu, D.; Yang, Z.; Ma, S.; Li, X.; Xiong, L. The OsMYB30 transcription factor suppresses cold tolerance by interacting with a JAZ protein and suppressing b-amylase expression. Plant Physiol. 2017, 173, 1475-1491. [CrossRef]

65. Zhang, P.; Wang, R.; Ju, Q.; Li, W.; Tran, L.P.; Xu, J. The R2R3-MYB transcription factor MYB49 regulates cadmium accumulation. Plant Physiol. 2019, 180, 529-542. [CrossRef]

66. Benitez, E.R.; Hajika, M.; Yamada, T.; Takahashi, K.; Oki, N.; Yamada, N.; Nakamura, T.; Kanamaru, K. A Major QTL controlling seed cadmium accumulation in soybean. Crop Sci. 2010, 50, 1728-1734. [CrossRef]

67. Vollmann, J.; Lošák, T.; Pachner, M.; Watanabe, D.; Musilová, L.; Hlušek, J. Soybean cadmium concentration: Validation of a QTL affecting seed cadmium accumulation for improved food safety. Euphytica 2014, 203, 177-184. [CrossRef]

68. Clemens, S. Toxic metal accumulation, responses to exposure and mechanisms of tolerance in plants. Biochimie 2006, 88, 1707-1719. [CrossRef] [PubMed]

69. Liu, J.H.; Hou, H.; Zhao, L.; Sun, Z.J.; Lu, Y.F.; Li, H. Mitigation of Cd accumulation in rice from Cd-contaminated paddy soil by foliar dressing of S and P. Sci. Total Environ. 2019, 690, 321-328. [CrossRef] [PubMed]

70. Wu, Z.; Wang, F.; Liu, S.; Du, Y.; Li, F.R.; Du, R.Y.; Wen, D.; Zhao, J. Comparative responses to silicon and selenium in relation to cadmium uptake, compartmentation in roots, and xylem transport in flowering Chinese cabbage (Brassica campestris L. ssp. chinensis var. utilis) under cadmium stress. J. Exp. Bot. 2016, 131, 173-180. [CrossRef]

71. Li, Y.; Liang, X.F.; Huang, Q.Q.; Xu, Y.M.; Yang, F. Inhibition of Cd accumulation in grains of wheat and rice under rotation mode using composite silicate amendment. RSC Adv. 2019, 61, 35539-35548. [CrossRef]

72. Lux, A.; Vaculik, M.; Martinka, M.; Liskova, D.; Kulkarni, M.G.; Stirk, W.A.; Van, S. Cadmium induces hypodermal periderm formation in the roots of the monocotyledonous medicinal plant Merwilla plumbea. Ann. Bot. 2011, 107, 285-292. [CrossRef]

73. Sasaki, A.; Yamaji, N.; Yokosho, K.; Ma, J.F. Nramp5 is a major transporter responsible for manganese and cadmium uptake in rice. Plant Cell 2012, 24, 2155-2167. [CrossRef]

74. Uraguchi, S.; Kamiya, T.; Sakamoto, T.; Kasai, K.; Sato, Y.; Nagamura, Y.; Yoshida, A.; Kyozuka, J.; Ishikawa, S.; Fujiwara, T. Low-affinity cation transporter (OsLCT1) regulates cadmium transport into rice grains. Proc. Natl. Acad. Sci. USA 2011, 108, 20959-20964. [CrossRef]

75. Curie, C.; Panaviene, Z.; Loulergue, C.; Dellaporta, S.L.; Briat, J.F.; Walker, E.L. Maize yellow stripe1 encodes a membrane protein directly involved in Fe (III) uptake. Nature 2001, 409, 346-349. [CrossRef]

76. Murata, Y.; Ma, J.F.; Yamaji, N.; Ueno, D.; Nomoto, K.; Iwashita, T. A specific transporter for iron (III)-phytosiderophore in barley roots. Plant J. 2006, 46, 563-572. [CrossRef]

77. Koike, S.; Inoue, H.; Mizuno, D.; Takahashi, M.; Nakanishi, H.; Mori, S.; Nishizawa, N.K. OsYSL2 is a rice metal-nicotianamine transporter that is regulated by iron and expressed in the phloem. Plant J. 2004, 39, 415-424. [CrossRef]

78. Ogawa, I.; Nakanishi, H.; Ishimaru, Y.; Takahashi, M.; Mori, S.; Nishizawa, N.K. Iron deficiency enhanced Cd uptake and translocation by $\mathrm{Fe}^{2+}$ transporters, OsIRT1 and OsIRT2, in rice. Plant Cell Physiol. 2006, 47, S231.

79. Yoshihara, T.; Hodoshima, H.; Miyano, Y.; Shoji, K.; Shimada, H.; Goto, F. Cadmium inducible Fe deficiency responses observed from macro and molecular views in tobacco plants. Plant Cell Rep. 2006, 25, 365-373. [CrossRef] [PubMed]

80. Lanquar, V.; Lelièvre, F.; Barbier-Brygoo, H.; Thomine, S. Regulation and function of AtNRAMP4 metal transporter protein. Soil Sci. 2004, 50, 1141-1150. [CrossRef] 
81. Nevo, Y.; Nelson, N. The NRAMP family of metal-ion transporters. BBA-Mol. Cell Res. 2006, 1763, 609-620. [CrossRef]

82. Ishimaru, Y.; Takahashi, R.; Bashir, K.; Shimo, H.; Senoura, T.; Sugimoto, K.; Ono, K.; Yano, M.; Ishikawa, S.; Arao, T.; et al. Characterizing the role of rice NRAMP5 in manganese, iron and cadmium transport. Sci. Rep. 2012, 2, 286. [CrossRef]

83. Wu, D.; Yamaji, N.; Yamane, M.; Kashino-Fujii, M.; Sato, K.; Ma, J. The HvNramp5 transporter mediates uptake of cadmium and manganese, but not iron. Plant Physiol. 2016, 172, 1899-1910. [CrossRef]

84. Takahashi, R.; Ishimaru, Y.; Shimo, H.; Bashir, K.; Senoura, T.; Sugimoto, K.; Ono, K.; Suzui, N.; Kawachi, N.; Ishii, S.; et al. From laboratory to field: OsNRAMP5-knockdown rice is a promising candidate for $\mathrm{Cd}$ phytoremediation in paddy fields. PLoS ONE 2014, 9, e98816. [CrossRef]

85. Yamaji, N.; Sasaki, A.; Xia, J.X.; Yokosho, K.; Ma, J.F. A node-based switch for preferential distribution of manganese in rice. Nat. Commun. 2013, 4,1-11. [CrossRef]

86. Xia, J.; Yamaji, N.; Kasai, T.; Ma, J.F. Plasma membrane-localized transporter for aluminum in rice. Proc. Natl. Acad. Sci. USA 2010, 107, 18381-18385. [CrossRef]

87. Thomine, S.; Lelievre, F.; Debarbieux, E.; Schroeder, J.I.; Barbier-Brygoo, H. AtNRAMP3, a multispecific vacuolar metal transporter involved in plant responses to iron deficiency. Plant J. 2003, 34, 685-695. [CrossRef]

88. Thomine, S.; Wang, R.; Ward, J.M.; Crawford, N.M.; Schroeder, J.I. Cadmium and iron transport by members of a plant transporter gene family in Arabidopsis with homology to NRAMP genes. Proc. Natl. Acad. Sci. USA 2000, 97, 4991-4996. [CrossRef]

89. Li, L.; Liu, X.; Peijnenburg, W.J.G.M.; Zhao, J.; Chen, X.; Yu, J.; Wu, H. Pathways of cadmium fluxes in the root of the halophyte Suaeda salsa. Ecotoxicol. Environ. Saf. 2012, 75, 1-7. [CrossRef] [PubMed]

90. Demidchik, V.; Shabala, S.; Isayenkov, S.; Cuin, T.A.; Pottosin, I. Calcium transport across plant membranes: Mechanisms and functions. New Phytol. 2018, 220, 49-69. [CrossRef] [PubMed]

91. DeFalco, T.A.; Marshall, C.B.; Munro, K.; Kang, H.G.; Moeder, W.; Ikura, M.; Snedden, W.A.; Yoshioka, K. Multiple calmodulin-binding sites positively and negatively regulate Arabidopsis CYCLIC NUCLEOTIDE-GATED CHANNEL12. Plant Cell 2016, 28, 1738-1751. [CrossRef] [PubMed]

92. Jha, S.K.; Sharma, M.; Pandey, G.K. Role of cyclic nucleotide gated channels in stress management in plants. Curr. Genom. 2016, 17, 315-329. [CrossRef]

93. Lam, H.M.; Chiu, J.; Hsieh, M.H.; Meisel, L.; Oliveira, I.C.; Shin, M.; Coruzzi, G. Glutamate-receptor genes in plants. Nature 1998, 396, 125-126. [CrossRef]

94. Davenport, R. Glutamate receptors in plants. Ann. Bot. 2002, 90, 549-557. [CrossRef]

95. Aouini, A.; Matsukura, C.; Ezura, H.; Asamizu, E. Characterisation of 13 glutamate receptor-like genes encoded in the tomato genome by structure, phylogeny and expression profiles. Gene 2012, 493, 36-43. [CrossRef]

96. Ni, J.; Yu, Z.; Du, G.; Zhang, Y.; Taylor, J.L.; Shen, C.; Xu, J.; Liu, X.; Wang, Y.; Wu, Y. Heterologous expression and functional analysis of rice GLUTAMATE RECEPTOR-LIKE family indicates its role in glutamate triggered calcium flux in rice roots. Rice 2016, 9, 9. [CrossRef]

97. Montanini, B.; Blaudez, D.; Jeandroz, S.; Sanders, D.; Chalot, M. Phylogenetic and functional analysis of the Cation Diffusion Facilitator (CDF) family: Improved signature and prediction of substrate specificity. BMC Genom. 2007, 8, 107. [CrossRef]

98. Kawachi, M.; Kobae, Y.; Mimura, T.; Maeshima, M. Deletion of ahistidine-rich loop of AtMTP1, a vacuolar $\mathrm{Zn}^{2+} / \mathrm{H}^{+}$antiporter of Arabidopsis thaliana, stimulates the transport activity. J. Biol. Chem. 2008, 283, 8374-8383. [CrossRef] [PubMed]

99. Desbrosses-Fonrouge, A.G.; Voigt, K.; Schroder, A.; Arrivault, S.; Thomine, S.; Kramer, U. Arabidopsis thaliana MTP1 is a $\mathrm{Zn}$ transporter in the vacuolar membrane which mediates $\mathrm{Zn}$ detoxification and drives leaf $\mathrm{Zn}$ accumulation. FEBS Lett. 2005, 579, 4165-4174. [CrossRef] [PubMed]

100. Kawachi, M.; Kobae, Y.; Kogawa, S.; Mimura, T.; Kramer, U.; Maeshima, M. Amino acid screening based on structural modeling identifies critical residues for the function, ion selectivity and structure of Arabidopsis MTP1. FEBS J. 2012, 279, 2339-2356. [CrossRef] [PubMed]

101. Migocka, M.; Papierniak, A.; Kosieradzka, A.; Posyniak, E.; Maciaszczyk-Dziubinska, E.; Biskup, R.; Garbiec, A.; Marchewka, T. Cucumber metal tolerance protein CsMTP9 is a plasma membrane $\mathrm{H}^{+}$-coupled antiporter involved in the $\mathrm{Mn}^{2+}$ and $\mathrm{Cd}^{2+}$ efflux from root cells. Plant J. 2015, 84, 1045-1058. [CrossRef] [PubMed] 
102. Ueno, D.; Sasaki, A.; Yamaji, N.; Miyaji, T.; Fujii, Y.; Takemoto, Y.; Moriyama, S.; Che, J.; Moriyama, Y.; Iwasaki, K.; et al. A polarly localized transporter for efficient manganese uptake in rice. Nat. Plants 2015, 1, 1-8. [CrossRef]

103. Chen, Z.; Fujii, Y.; Yamaji, N.; Masuda, S.; Takemoto, Y.; Kamiya, T. Mn tolerance in rice is mediated by MTP8.1 a member of the cation diffusion facilitator family. J. Exp. Bot. 2013, 64, 4375-4387. [CrossRef]

104. Kim, D.; Gustin, J.L.; Lahner, B.; Persans, M.W.; Baek, D.; Yun, D.J.; Salt, D.E. The plant CDF family member TgMTP1 from the Ni/Zn hyperaccumulator Thlaspi goesingense acts to enhance efflux of $\mathrm{Zn}$ at the plasma membrane when expressed in Saccharomyce cerevisiae. Plant J. 2004, 39, 237-251. [CrossRef]

105. Deng, F.; Yamaji, N.; Xia, J.; Ma, J.F. A member of the heavy metal P-type ATPase OsHMA5 is involved in xylem loading of copper in rice. Plant Physiol. 2013, 163, 1353-1362. [CrossRef]

106. Hussain, D.; Haydon, M.J.; Wang, Y.; Wong, E.; Sherson, S.M.; Young, J.; Camakaris, J.; Harper, J.F.; Cobbett, C.S. P-type ATPase heavy metal transporters with roles in essential zinc homeostasis in Arabidopsis. Plant Cell 2004, 16, 1327-1339. [CrossRef]

107. Lekeux, G.; Crowet, J.; Nouet, C.; Joris, M.; Jadoul, A.; Bosman, B.; Carnol, M.; Motte, P.; Lins, L.; Galleni, M.; et al. Homology modeling and in vivo functional characterization of the zinc permeation pathway in a heavy metal P-type ATPase. J. Exp. Bot. 2019, 70, 329-341. [CrossRef]

108. Uraguchi, S.; Kamiya, T.; Clemens, S.; Fujiwara, T. Charaterization of OsLCT1, a cadmium transporter from Indica rice (Oryza sativa). Physiol. Plant. 2014, 151, 339-347. [CrossRef] [PubMed]

109. Song, W.Y.; Park, J.; Mendoza-Cozatl, D.G.; Suter-Grotemeyer, M.; Shim, D.; Hortensteiner, S.; Geisler, M.; Weder, B.; Rea, P.A.; Rentsch, D. Arsenic tolerance in Arabidopsis is mediated by two ABCC-type phytochelatin transporters. Proc. Natl. Acad. Sci. USA 2010, 107, 21187-21192. [CrossRef] [PubMed]

110. Brunetti, P.; Zanella, L.; De, P.A.; Di, L.D.; Cecchetti, V.; Falasca, G. Cadmium-inducible expression of the ABC-type transporter AtABCC3 increases phytochelatin-mediated cadmium tolerance in Arabidopsis. J. Exp. Bot. 2015, 66, 3815-3829. [CrossRef] [PubMed]

111. Becher, M.; Talke, I.N.; Krall, L.; Kramer, U. Cross-species microarray transcript profiling reveals high constitutive expression of metal homeostasis genes in shoots of the zinc hyperaccumulator Arabidopsis halleri. Plant J. 2004, 37, 251-268. [CrossRef]

112. Morel, M.; Crouzet, J.; Gravot, A.; Auroy, P.; Leonhardt, N.; Vavasseur, A. AtHMA3, a P $\mathrm{P}_{1 \mathrm{~B}}$-ATPase allowing $\mathrm{Cd} / \mathrm{Zn} / \mathrm{Co} / \mathrm{Pb}$ vacuolar storage in Arabidopsis. Plant Physiol. 2009, 149, 894-904. [CrossRef]

113. Chao, D.Y.; Silva, A.; Baxter, I.; Huang, Y.S.; Nordborg, M.; Danku, J. Genome-wide association studies identify heavy metal ATPase3 as the primary determinant of natural variation in leaf cadmium in Arabidopsis thaliana. PLoS Genet. 2012, 8, e1002923. [CrossRef]

114. Liu, H.; Zhao, H.; Wu, L.; Liu, A.; Zhao, F.J.; Xu, W. Heavy metal ATPase3 (HMA3) confers cadmium hypertolerance on the cadmium/zinc hyperaccumulator Sedum plumbizincicola. New Phytol. 2017, 215, 687-698. [CrossRef]

115. Korenkov, V.; Hirschi, K.; Crutchfield, J.D.; Wagner, G.J. Enhancing tonoplast Cd/H antiport activity increases $\mathrm{Cd}, \mathrm{Zn}$, and $\mathrm{Mn}$ tolerance, and impacts root/shoot Cd partitioning in Nicotiana tabacum L. Planta 2007, 226, 1379-1387. [CrossRef]

116. Korenkov, V.; King, B.; Hirschi, K.; Wagner, G.J. Root-selective expression of AtCAX4 and AtCAX2 results in reduced lamina cadmium in field-grown Nicotiana tabacum L. Plant Biotechnol. J. 2009, 7, 219-226. [CrossRef]

117. Migocka, M.; Kosieradzka, A.; Papierniak, A.; Maciaszczyk-Dziubinska, E.; Posyniak, E.; Garbiec, A.; Filleur, S. Two metal-tolerance proteins, MTP1 and MTP4, are involved in Zn homeostasis and Cd sequestration in cucumber cells. J. Exp. Bot. 2014, 66, 1001-1015. [CrossRef]

118. Migocka, M.; Papierniak, A.; Maciaszczyk-Dziubinska, E.; Pozdzik, P.; Posyniak, E.; Garbiec, A.; Filleur, S. Cucumber metal transport protein MTP8 confers increased tolerance to manganese when expressed in yeast and Arabidopsis thaliana. J. Exp. Bot. 2014, 65, 5367-5384. [CrossRef] [PubMed]

119. Podar, D.; Scherer, J.; Noordally, Z.; Herzyk, P.; Nies, D.; Sanders, D. Metal selectivity determinants in a family of transition metal transporters. J. Biol. Chem. 2012, 287, 3185-3196. [CrossRef] [PubMed]

120. Takahashi, R.; Ishimaru, Y.; Shimo, H.; Ogo, Y.; Senoura, T.; Nishizawa, N.K.; Nakanishi, H. The OsHMA2 transporter is involved in root to shoot translocation of $\mathrm{Zn}$ and $\mathrm{Cd}$ in rice. Plant Cell Environ. 2012, 35, 1948-1957. [CrossRef] [PubMed]

121. Sasaki, A.; Yamaji, N.; Ma, J. Overexpression of OsHMA3 enhances Cd tolerance and expression of Zn transporter genes in rice. J. Exp. Bot. 2014, 65, 6013-6021. [CrossRef] [PubMed] 
122. Kopittke, P.M.; DeJonge, M.D.; Wang, P.; Mckenna, B.A.; Lombi, E.; Paterson, D.J. Laterally resolved speciation of arsenic in roots of wheat and rice using fluorescence-XANES imaging. New Phytol. 2013, 201, 1251-1262. [CrossRef] [PubMed]

123. Martinoia, E.; Meyer, S.; De Angeli, A.; Nagy, R. Vacuolar transporters in their physiological context. Annu. Rev. Plant. Biol. 2012, 63, 183-213. [CrossRef]

124. Mathys, W. The role of malate, oxalate, and mustard oil glucosides in the evolution of zinc resistance in herbage plants. Physiol. Plant. 1997, 40, 130-136. [CrossRef]

125. Ortiz, D.F.; Kreppel, L.; Speiser, D.M.; Scheel, G.; McDonald, G.; Ow, D.W. Heavy metal tolerance in the fission yeast requires an ATP-binding cassette type vacuolar membrane transporter. EMBO J. 1992, 11, 3491-3499. [CrossRef]

126. Ortiz, D.F.; Ruscitti, T.; McCue, K.F.; Ow, D.W. Transport of metal- binding peptides by HMT1, a fission Yeast ABC-type vacuolar membrane protein. J. Biol. Chem. 1995, 270, 4721-4728. [CrossRef]

127. Kuriakose, S.V.; Prasad, M.N.V. Cadmium stress affects seed germination and seedling growth in Sorghumbicolor (L.) Moench by changing the activities of hydrolyzing enzymes. Plant Growth Reg. 2008, 54, 143-156. [CrossRef]

128. Sooksa-Nguan, T.; Yakubov, B.; Kozlovskyy, V.; Barkume, C.M.; Howe, K.J.; Thannhauser, T.W. Drosophila ABCtransporter, DmHMT-1, confers tolerance to cadmium. DmHMT-1 and its yeast homolog, SpHMT-1, are not essential for vacuolar phytochelatin sequestration. J. Biol. Chem. 2009, 284, 354-362. [CrossRef] [PubMed]

129. Vatamaniuk, O.K.; Bucher, E.A.; Sundaram, M.V.; Rea, P.A. CeHMT-1, a putative phytochelatin transporter, is required for cadmium tolerance in Caenorhab ditiselegans. J. Biol. Chem. 2005, 280, 23684-23690. [CrossRef] [PubMed]

130. Lu, Y.P.; Li, Z.S.; Drozdowicz, Y.M.; Hortensteiner, S.; Martinoia, E.; Rea, P.A. AtMRP2, an Arabidopsis ATP binding cassette transporter able to transport glutathione S-conjugates and chlorophyll catabolites: Functional comparisons with AtMRP1. Plant Cell 1998, 10, 267-282. [PubMed]

131. Park, J.; Song, W.Y.; Ko, D.; Eom, Y.; Hansen, T.H.; Schiller, M.; Lee, T.G.; Martinoia, E.; Lee, Y. The phytochelatin transporters AtABCC1 and AtABCC2 mediate tolerance to cadmium and mercury. Plant J. 2012, 69, 278-288. [CrossRef]

132. Song, W.Y.; Mendoza-Cozatl, D.; Lee, Y.; Schroeder, J.; Ahn, S.N.; Lee, H.S. Phytochelatin-metal(loid) transport into vacuoles shows different substrate preferences in barley and Arabidopsis. Plant Cell Environ. 2014, 37, 1192-1201. [CrossRef]

133. Miyadate, H.; Adachi, S.; Hiraizumi, A.; Tezuka, K.; Nakazawa, N.; Kawamoto, T. OsHMA3, a P-1B-type of ATPase affects root-to-shoot cadmium translocation in rice by mediating efflux into vacuoles. New Phytol. 2011, 189, 190-199. [CrossRef]

134. Zhang, J.; Zhang, M.; Shohag, M.J.; Tian, S.; Song, H.; Feng, Y. Enhanced expression of SaHMA3 plays critical roles in Cd hyperaccumulation and hypertolerance in Cd hyperaccumulator Sedum alfredii Hance. Planta 2016, 243, 577-589. [CrossRef]

135. Oomen, R.J.; Wu, J.; Lelievre, F.; Blanchet, S.; Richaud, P.; Barbier-Brygoo, H. Functional characterization of NRAMP3 and NRAMP4 from the metal hyperaccumulator Thlaspi caerulescens. New Phytol. 2009, 181, 637-650. [CrossRef]

136. Baliardini, C.; Meyer, C.L.; Salis, P.; Saumitou-Laprade, P.; Verbruggen, N. CATION EXCHANGER1 cosegregates with cadmium tolerance in the metal hyperaccumulator Arabidopsis halleri and plays a role in limiting oxidative stress in Arabidopsis spp. Plant Physiol. 2015, 169, 549-559. [CrossRef]

137. Lanquar, V.; Lelièvre, F.; Bolte, S.; Hamès, C.; Alcon, C.; Neumann, D. Mobilization of vacuolar iron by AtNRAMP3 and AtNRAMP4 is essential for seed germination on low iron. EMBO J. 2005, 24, 4041-4051. [CrossRef]

138. Boominathan, R.; Doran, P.M. Organic acid complexation, heavy metal distribution and the effect of ATPase inhibition in hairy roots of hyperaccumulator plant species. J. Biotechnol. 2003, 101, 131-146. [CrossRef]

139. Sun, R.L.; Zhou, Q.X.; Jin, C.X. Cadmium accumulation in relation to organic acids in leaves of Solanum nigrum L. as a newly found cadmium hyperaccumulator. Plant Soil 2006, 285, 125-134. [CrossRef]

140. Ehsan, S.; Ali, S.; Noureen, S.; Mahmood, K.; Farid, M.; Ishaque, W.; Shakoor, M.B.; Rizwan, M. Citric acid assisted phytoremediation of cadmium by Brassica napus L. Ecotoxicol. Environ. Saf. 2014, 106, 164-172. [CrossRef] 
141. Yang, H.; Yang, Z.M.; Zhou, L.X.; Wong, J.W. Ability of Agrogyron elongatum to accumulate the single metal of cadmium, copper, nickel and lead and root exudation of organic acids. J. Environ. Sci. 2001, 13, 368-375.

142. Price, M.B.; Kong, D.; Okumoto, S. Inter-subunit interactions between Glutamate-Like Receptors in Arabidopsis. Plant Signal. Behav. 2013, 12, e27034. [CrossRef]

(C) 2020 by the authors. Licensee MDPI, Basel, Switzerland. This article is an open access article distributed under the terms and conditions of the Creative Commons Attribution (CC BY) license (http://creativecommons.org/licenses/by/4.0/). 